\title{
Sociolinguistic Analysis of the Language of Palm Wine Drinkers' Club (Kegite)
}

\author{
Okeke, Gloria Tochukwu \\ Department of Linguistics, Igbo and Other Nigerian Languages, University of Nigeria, Nsukka, Enugu state, Nigeria \\ Mbah, Boniface Monday \\ Department of Linguistics, Igbo and Other Nigerian Languages, University Of Nigeria, Nsukka, Enugu state, Nigeria \\ Okeke, Chukwuma Onyebuchi \\ Department of Linguistics, Igbo and Other Nigerian Languages, University of Nigeria, Nsukka, Enugu State, Nigeria
}

\begin{abstract}
This paper analyses the language of Palm Wine Drinkers' Club in Nigeria, known as Kegite Club. The paper's main objective is to examine the pattern and language use of the Kegite club and highlight how it departs from the linguistic pattern found within the general society where the club exists. By using Giles (1971) Communication Accommodation Theory, the paper demonstrates how Kegite members converge with their members by using the Kegite linguistic patterns and diverge from non-members, because non members do not understand the Kegite linguistic pattern, notwithstanding the fact that the English language forms the background of the Kegite language. The oral and documented data collected through interview and participant observation were quantitatively analyzed and categorized in groups based on the different features of the Kegite language observed. The findings of the study show that the formation, structure and language use of the Kegite club exhibit a kind of technical language attributes that are quite peculiar to it. Hence, this study classifies it as a specific type of slang.
\end{abstract}

Index Terms-Kegite, language variety, slang, convergence, divergence and Communication Accommodation Theory

\section{INTRODUCTION}

Language use involves formal and informal ways of communication. Formal usage of language is characterised by standard expressions while informal usage comprises slang, pidginise forms, colloquial usages, etc. Language use, whether formal or informal, takes place in human society; hence, an interesting relationship exists between language and society in general; and language and situation(s) of use in particular. It is important to note here that the sense of 'language' as used in this paper is any symbol of sign that is agreed-upon as a means of conveying meaning from one person to another within a given group of people as observed by Ndimele (1999).

Many a time in communication, meaning is derived or determined by the situation in which language is used, and often, meaning is conventionally agreed upon by a speech community. In other words, meaning is complete when it is situated and whatever meaning arrived at is dependent on the agreement the speakers have, hence, the issue of acceptability is sine qua non in human communication, (communicative competence). This study looks at the language of the Kegite club (a palm wine drinking club in Nigerian Universities and beyond) and how they manifest their ingroup-ness through language. According to Afolabi (2011), Kegite members communicate effectively in their language, hence the Kegite language is acceptable to members and also, it serves as the language of wider communication for all members within Nigeria and beyond. The problem of the study, therefore, is to ascertain how the language of the Palm Wine Drinkers' Club (Kegite) is strange to the general public even though it developed from the English language and the local language(s) of the immediate environment. The main objective of this study is to examine the pattern and usage of the Kegite language in the University of Nigeria, Nsukka which set it apart from the foundational language(s), which in turn make it difficult for the comprehension of non-members; thereby hampering communication between the group and the general public.

\section{OVERVIEW OF THE PALM WiNe DRINKERS’ CluB}

According to Gilbert (2013), the Kegite club is a palm-wine-drinking club “...that originated in 1962 at the Ibadan campus of the then University of Ife (now, Obafemi Awolowo University (OAU), Ile-Ife, Nigeria" (p.1), by some traditionalist students. The students usually came together every evening to drink palm wine after the day's work. It was in one of such evenings that they thought it wise to form a socio-cultural club. This idea flourished and they appointed officers to oversee the affairs of the club. Gilbert further states that the students also agreed that the president of the club should be addressed as chief to depict a typical African traditional setting. Consequently, Prof. Olusegun Adeshina was the first chief to be coroneted by the club. They established the Kegite club in order to avail themselves of a recreation 
opportunity. As it stands now, members are welcomed from any part of the society, though it is still situated in tertiary institutions. However, the members are mostly students. According to Gilbert (2013), the aim of the club is primarily to promote African culture. Therefore, the club is known for its music and dancing. It is a social club that has expanded so much that it can be referred to as a community with its own traditions and culture. Kegite club according to Afolabi (2011) is undoubtedly the most popular socio-cultural group in tertiary institutions in Nigeria with members not just in Nigeria but also in other Africa countries, Europe, Asia and the United States of America. Just as language performs the unification function generally, the Kegite language, as the researchers observe is characterised by peculiar expressions that are only used and understood among the members. These peculiar expressions have been adopted among the members of the club, and only members or close associates of the club can decode the language.

As was earlier stated, Kegite club exists in tertiary institutions; therefore, they exist in communities that already have language of general communication. In other words, the language of the Kegite exists alongside the language of the general public in the linguistic environment where it is found. The language of the Kegite Club is generally fed from the language of the general public within the environment of the club. Afolabi (2011), points out that the language of the Kegite club has its root in the English language. This can be attributed to the fact that English is the lingua franca of Nigeria. In addition to English, "other indigenous Nigerian languages (Igbo, Yoruba and Hausa), alongside the Nigerian Pidgin English (NPE) and French are used to furnish the Kegite language," says (Afolabi, 2011, p.16).

\section{THEORETICAL STUDIES}

According to Hudson (1996), language varies geographically because people living far from one another are likely to speak more differently than those living close to one another. On the other hand, those living close to one another have more contact with one another than those living far from one other. However, people living close to one another, sometimes, speak differently. Closeness and distance are, therefore, very essential in language variety. Furthermore, Hudson approaches the organisation of society from two angles viz: social network and social stratification. Social stratification has to do with hierarchical structure of a society resulting from inequalities of wealth and power while social network has to do with dimensions of solidarity between individual members of society in their everyday relations. However, in this paper, as shall be observed in subsequent sections, even though members of speech communities (in which Kegite groups exist) have very close contact with Kegite club members, they are very far apart when it comes to understanding and speaking the Kegite language.

Dittmar (1976) distinguishes between four forms of linguistic variety: standard, regional, social and functional.

a. The standard variety is that variety that is lawfully recognised and approved as an acceptable medium of communication in a society. It is the variety mostly used in official institutions and formal contexts. It is taught and learnt in schools and carried with it some amount of prestige.

b. Regional varieties are classified as dialects when they are developed in particular areas of settlement and are historically conveyed. Their major function is in oral communication as against the standard variety. This variety is not rigidly codified. Sometimes, dialects are raised to the level of standard variety and sometimes they disappear under the influence of urbanisation.

c. Social varieties or sociolect are speech conventions of groups that are frequently subjected to a large-scale prestige evaluation by other social groupings (e.g. socioeconomically or ideologically repressed classes) and can become the subject for conflict between them.

d. Functional varieties differ from the other varieties that have been mentioned in that their usage runs straight across the dimensions set by the standard variety, the sociolect or the dialect. They can be connected with specific interactions, with institutions or with conditions of the place of work, with formal or informal situations, with the speaker's idiosyncrasies, etc. Functional varieties are frequently technical languages, special languages, slang or commercial languages, (pp. 107-110).

From the variety types enumerated above, the kind of language variety that Kegites club falls within is functional variety, i.e., language of specific interaction. This is also the class where technical language (that is, registers and jargons), slang and the likes belong to.

Halliday (1964) says that technical and professional occupations have given rise to registers that are often characterised by vocabularies that are beyond the range of the ordinary educated man and with unique sentence patterns that are often restricted. A profession's register is made up of peculiar vocabularies, expressions, often referred to as jargon, which according to Crystal (1994), is a collective term used to refer to technical vocabulary and expression used in communication among specialists, which are not intelligible to the general public.

On the other hand, the term slang has been defined by Mish (2003) as an "...informal nonstandard vocabulary composed typically of coinages, arbitrary changed words, and extravagant, forced, or facetious figures of speech," (p. 1170). Borrowing a leaf from Mish (2003), Ratna (2010) sees slang as informal and nonstandard words and phrases which originate in subcultures within a society. Ratna's definition is in line with Jorgen (2010)'s view of slang as an alternative linguistic form that forms part of daily interaction within a community with distinct and identifiable groups or subgroups. Mish (2003) and Ratna (2010) stress that when a speaker uses slang, it suggests that he is familiar with the hearer's group or subgroup and that it serves as a distinguishing factor of in-group identity. Slang, just like any other variety of language, must gain acceptance by the group members for it to become part of the group's vocabulary. 
Therefore, for any linguistic expression to survive, it must be widely accepted by the group. Mish (2003) and Ratna (2010) conclude that individuals use slang because they desire to be unique. Furthermore, Jorgen (2010) observes that slang often stems from conflicts in fundamental socio-psychological values. When an individual applies language in a new and novel way to express opposition, ridicule, or contempt, often tinged with sharp wit and humour, he or she may be an unconscious creator of a slang item. If the speaker happens to belong to a group, then the expression will gain currency based upon the unanimity of attitude within the group.

Some of the types of slang identified in Ari (2011) include: "Cockney, public house, workmen, tradesmen, society and soldiers slang”, (pp. 10-19). These classes notwithstanding, Burdova (2009) in line with Maottiello's (2008) view observes, "the nature of slang is characterised by extent and it is all-encompassing." Therefore, "it allows for further sub-distinction between specific and general slang terminology," (p. 25). She simply explains that specific slang is the slang

...used by members of a particular group to show their respect for that group and solidarity with other group members. It is also used in order to underline speakers' identity, social status, age, education, special interests as well as their geographical background.

Specific slang is mostly used by speakers of similar age like teenagers (example: chick for 'a girl' and cool for 'okay'), similar occupation like military (example: ground nyash 'sit on the bare floor/ground), speakers who share similar lifestyle like the drunkards, homosexuals, drug addicts (example: grass for 'marijuana') or speakers who share the same living conditions like armed robbers and prostitutes.

Also, Burdova (2009) argues that general slang is the slang used by speakers to evade conventions and formality. "It is used instead of clichés and standard language to change the level of formality", (p. 26). She equally notes that words or expressions may fall into both specific and general slang category depending on their contexts. She cites example from Mattiello (2008) with the word grass being a specific drug slang 'marijuana' whereas in general slang it stands for 'green vegetables'.

According to (Spolsky, 1998, p.35), a language variety is considered slang when it possesses the following characteristics:

1. A set of expressions marked by its rejection of formal rules, its comparative freshness and its use to claim solidarity.

2. Slang regularly transgresses other social norms, making free use of taboo expression.

3. Slang arises as vocabulary which is used by a particular social group with specific purpose, for example, as a device for familiarising a conversation.

4. Slang comes in the form of new words with new meanings or old words with new meanings.

People use slang for a number of reasons. Partridge (1933) in (Jorgen, 2010, pp. 4-5) and Zazulak (2016) provide a number of reasons for which people use slang which are: to show that they are in high spirit, self display, to be different or novel, to avoid clichés (actuated by impatience with existing terms), to enrich the language, to lend an air of solidarity, to soften tragedy or to make serious life issues like death or madness sound less-serious, to reduce seriousness of conversation, to induce either friendliness or intimacy, to be 'in the swim' (to show that one belongs to a certain group or to establish contact), to be secret - not understood by those around, among others.

The Kegite language, as observed by the researchers maybe a form of an exclusive code used by the members of the club and understood by them alone. It may also be adjudged an argot. Argot is a word of French origin which means a secret slang language of a particular group used to exclude outsiders from understanding the group's conversation. According to Valdman (2000), words and constructions that form the vocabulary of argot are however, drawn from ordinary common and dominant language. He opines that under the strictest sense, an argot is a 'proper' language which has its own grammar and style. However, he notes that it is rare to come by such completely secret language because the speakers of argot usually have some common public language, which serves as the basis for the argot. A common kind of argot is mainly a version of a public language(s), except that a part of the vocabulary is replaced by words which are quite strange to the larger public. So, going by Veldman's 'strict' definition of argot, we would not say that the language of the Kegite is an argot, rather, we would like to identify this unique variety simply as a specific type of slang following Mattiello's (2008) and Burdova (2009) definitions, classification and characterisation of slang. And what characteristically distinguishes slang from other forms of language is that it is fundamentally social and as such, it is often associated with a particular group of speakers. It is also necessary to point out that slang is one thing that cannot be adequately studied from a pure linguistic point of view. Therefore, we see slang in this paper as a social and aesthetic phenomenon, which can be perceived and appraised rather than as a purely linguistic concept.

On the other hand, language variation is a sociolinguistic phenomenon that has been studied from various perspectives. One of such perspective is the Communication Accommodation Theory (CAT). It is a theoretical approach to the study of language variety. CAT, initially known as Speech Accommodation Theory, is a sociopsychological theory propounded by Giles (1971) to specify conditions under which individuals would desire to reduce or stress the social distance between those they are interacting with (i.e. by either accommodating or not accommodating). CAT posits that individuals do not interact with every person in the same way but communication patterns are always adjusted to match conversational partners (be they close friends or despicable felons). According to Giles and Baker (2008), although CAT indicates different ways through which interlocutors can reduce or widen social 
distances, convergence and divergence are the most prominent. Street and Giles (1982) observe that convergence is a movement towards a communicative partner because of a conscious or unconscious need for social integration, seeking or showing approval, identification or communication effectiveness with one another. On the other hand, Coupland and Giles (1988) assert that divergence is a movement away from communicative partner in order to maintain social distance.

This paper, therefore, adopts the communication accommodation theory as put forward by Giles (1971). CAT stresses the role of accommodation in communication. It asserts that interlocutors communicate to signify mutual attitude toward one another. Consequently, communication can serve as a barometer, which could be used to measure social distance that exists between individuals. According to Giles and Ogay (2007), language in communication moves individuals closer and away from one another. This either directional movement (that is, movement of individuals closer to or away from one another) is achieved by varying communication behaviour. It is this characteristic flexibility in language behaviour that is known as accommodation. CAT according to Giles, Coupland and Coupland (1991), assumes that language functions as an indication of both individual's and group's need to interact socially with others and also as an indication of the aspiration to gain social approval. The concept of social identification through communication is of paramount importance to CAT. Hence, CAT posits that interlocutors, through language use, accommodate to become similar to their communicative partners. This is called convergence. In the words of Giles and Coupland (1991), convergence indicates “a speaker's or a group's need (often non-conscious) for social integration or identification with one another", (p. 72). Therefore, Giles and Ogay (2007) say that the desire to belong to a group and shift towards a particular linguistic style in order to identify with that group is achieved through efficient communication. Giles and Coupland (1991) observe that interlocutors are psychologically brought closer and communication is also enhanced through accommodation. On the other hand, Giles and Ogay (2007) note that accommodation helps speakers to differentiate themselves from others and to communicate that they belong to a particular group which others do not. This is called divergence. Giles, et al (1991) opine that the balance between convergence and divergence is very important in communicative activities and this makes interlocutors to assume the communicative pattern that is typical of their group so as to "maintain a sense of community or fellowship". Wilson (2007) and Zotevska (2013) also assert that apart from maintaining a sense of fellowship, group members also emphasise their style of speech and recognise the difference between them and relevant out-groups. Therefore, the function of communication is to ascertain identity and/or confirm or sustain group membership through accommodation. For this reason, each group fashions out a unique linguistic pattern, which characterises them and is also cherished among the members.

Every communicative event has a goal to achieve. Hence, 'communication is goal directed' as noted in (Wilson, 2007, p.79). This implies that communication is not an erratic event but one with specific goal(s) to achieve. Wilson's definition of communicative goals as that future states, which a speaker desires to attain or maintain, suggests that various goals that a speaker sets out to achieve through social interactions are accomplished by the use of language. Through the application of accommodation (either by convergence or divergence), the anticipated goal of speakers are made known.

From the above theoretical overview, it could be observed that language, being highly heterogeneous, can vary based on certain factors. Language varies from one place to another, from one social group to another and from one situation to another. The present study, by using CAT studies language use among the Kegite club members to show how, by communicating the way they do, members achieve in-group allegiance (convergence) and mark themselves off from other members of the society (divergence), who share general linguistic background with them.

\section{Methodology}

This study is a survey research work designed to be in conformity with the standard procedures obtainable in the study of observed language behaviour. The article sets out to examine language use among the Kegites within the University of Nigeria, Nsukka, to ascertain how members of the club use the language to establish group identity and also to create a social distance between the group and the general public. Although the Kegite club can be found in many tertiary institutions in Nigeria and outside Nigeria, this study, by adopting purposive sampling procedure, studies the University of Nigeria, Nsukka (UNN) branch (Ilya du Nkasu). The UNN branch is the oldest ilya - 'branch' in the Eastern zone (Enuanaebo hemisphere) as well as the zone's headquarters. The Kegite branch in the UNN has about one hundred and fifty student members, who are used for this study. By adopting the qualitative method of data collection, data were elicited from Kegite members in the nine faculties in the University of Nigeria, Nsukka. The respondents were made up of mainly youths and few older persons who are in different academic levels in the University. The bulk of the corpora used for the study was directly elicited from the respondents through mass observation, where the group was observed (because they perform openly in evenings and in some social gatherings) and in their in-house interactions recorded through a field assistant, who is a member, since it is difficult for the researchers to do so themselves. The researchers also elicited data from the Kegite handbook, book of bookosis and the club's social network pages. The data collected both orally and from the Kegite members were analyzed quanlitatively, categorised accordingly based on different features of the language as presented in section five. 


\section{Data PRESEntation AND AnAlysis}

Before now, as a former chief of the Kegite club in its world headquarters, Uppermost Shrine, University of Ife, IleIfe, Nigeria, Oladokun (1982) discusses the Kegite club and provides the background information on the club. His work presents the history, vision or aim of the club. He explains some of the traditions and customs of the Kegite club as well as provides a few slogans used in the club among which include: Okpekerization - woo a woman, karabilty - destiny; One finger salute - a greeting pattern, chief - president, among few others.

Afolabi (2011) in his brief analysis examines the language of the Kegite. His work provides some expressions used by members of the club and analyses them to show how the group has, over the time, evolved a complete language of their own. Afolabi (2011) concludes by asserting that he has discovered that "the syntactic or grammatic [sic] analysis of the Kegite language are featured, the place of subject, predicator, complement and adjunct are also consciously presented as seen in some certain Kegites expressions", (p. 4). He, therefore, demonstrates how the group has successfully evolved a language of their own. Afolabi (2011) is related to this work in the sense that it studies Kegite language but differs from it because the present study looks at how Kegite members manipulate the linguistic elements (which they share with other members of the general society) at their disposal to create expressions which they in turn use to create social distance between the group and out-group members of the society.

In this section, Kegite expressions are presented and qualitatively analysed using CAT to demonstrate the principles of convergence and divergence. Here, we present and discuss the Kegite expressions by grouping them based on their linguistic features and the analysis done using CAT.

TABLE 1:

EXPRESSIONS SHOWCASING CREATIVITY, PRODUCTIVITY AND ARBITRARY NATURE OF LANGUAGE

\begin{tabular}{|c|c|c|}
\hline $\mathrm{S} / \mathrm{N}$ & Kegite expressions & Gloss/Meaning \\
\hline 1 & AB Chief/Chiefo & The incumbent president \\
\hline 2 & X Chief & The immediate past president \\
\hline 3 & XYZ Chief & The chief that handed over to the XY president \\
\hline 4 & Archival Chiefesis & Former presidents for over five (5) years \\
\hline 5 & Martial & Provost \\
\hline 6 & Parrot & Public relation officer/Information officer \\
\hline 7 & World bank/CBN & Treasurer \\
\hline 8 & Philosofa & Teacher of those who are to be liberated (admitted into the club) \\
\hline 9 & Spider & Designer of Kegites regalia and other Kegites's materials \\
\hline 10 & Feda & Secretary of the club (when writing was done using feather and ink) \\
\hline 11 & Cricket/Sungito & Song leader \\
\hline 12 & Drummito & Drummer \\
\hline 13 & HOD (Head of Drummisis) & The member in charge of drums \\
\hline 14 & Zoo Commandant & Member in charge of the place where new members are groomed \\
\hline 15 & B ECOWAS & Chorus (calling for members to 're-echo') \\
\hline 16 & Emblem & Local calabash \\
\hline 17 & Receipt & A leaf one brings after urinating and it must be a green leaf with apex and stalk still intact \\
\hline 18 & Imbibe & Drink (palm wine) \\
\hline 19 & Destroy & Drink (any other drink outside palm wine) \\
\hline 20 & Titration & Urination/defecation \\
\hline 21 & Gyration & Making of music and the dancing that typically accompanies it \\
\hline 22 & Mutation & Meeting of the Kegite club \\
\hline 23 & Vibrate & Talk/speak \\
\hline 24 & Ketekete & Vehicle \\
\hline 25 & Karability & Destiny \\
\hline 26 & Karid & Member/(you) belong \\
\hline 27 & Comrado/Kongosis/komrad & Student members \\
\hline
\end{tabular}

A look at Table (1) shows creativity as well as arbitrary nature of language. For instance, the use of $A B$ for 'current', 'present' or 'incumbent'; $X Y$ for 'immediate past' and $X Y Z$ for 'former, before the ' $X Y$ ', archival for 'one-time', (observe examples 1-4 in Table I). This shows how words can be created and re-created by language users based on the arrangement of letters, that is, letters that come first and the ones that come last. Examples (5-14) in Table I show how the members of the club have creatively used names of items or concepts to name executive posts in the club. A look at these names shows that the names used, somehow depict the functions performed by the office holders. For instance, martial for 'provost', one whose job is to see that there is order during gatherings; parrot for 'information officer', who is saddled with the responsibility of passing across information to members through speech; world bank/CBN(Central Bank of Nigeria) for 'treasurer', who keeps money for the club, among others. It could be observed that these words are metaphorically used. Again, the use of feda (truncated form for feather) for 'secretary' reminds one of when writing was basically done with refillable inks, using plumes. Also, examples (15-27) continue to demonstrate how language is creative. We can also observe that some of these words are words from the general society, with special meanings attached to them. Examples of such words are receipt and destroy, which are English words and ketekete, a Yoruba word for 'Donkey'. The new meanings are usually based upon fanciful and creative metaphors and metonymies. However, some of the expressions like karid (from 'carried'), akarability (from 'akara aka' in Igbo, which means 
'destiny'), kongosis, drummito (from 'drum') and sungito (from song') are entirely new coinages. These coinages are in line with Mish's (2003) submission that slangs are composed of coinages and arbitrarily changed words.

In addition, one of the major properties of language is arbitrariness. By language being arbitrary, it means that both word-forms and their meanings are randomly assigned. What this implies is that the speech sounds of a language are conventionally combined to form a meaningful word in a language only because (i) the users of the language agreed that the pattern of combination is right and acceptable (for instance, c-a-t 'cat' is right and a-t-c 'atc' is wrong in English) and (ii) the result of the combination should refer to or mean a particular thing/concept/idea in the language. The language of the Kegites exhibits the quality of arbitrariness in no small measure. For example, $A B, X Y$, spider (Table 1, examples 1, 2 and 8) and indeed, all the Kegite expressions presented in this paper are meaningful within the contexts where they are used, mainly because they have gained acceptance within these contexts. Observe the contextual uses of some of the words in Table 1. Note that in the sentences below, the words in question are in bold italics

1a. ... acting within those powersis, all those comradic powersis, all those Kongosis powersis... powersis to keg and dekeg...

b. ...acting within the powers, every power pertaining to the affairs of the Kegite club...the powers to officially approve of student membership and the powers to suspend a member...

2a. Muanawelus, the royal palm wine Majesty, AB Chiefo Nnanna Kenneth ... the 36th of Nkassu do hereby....bless all...

b. Me(I), his royal majesty of palm wine, Incumbent President Nnanna Kenneth... the 36th president of Kegite club, University of Nigeria, Nsukka branch do hereby... bless all...

3a. Muanawelus... do hereby do with no duress by mountain dew or morning dew bless all am karid...

b. Me (I)...do hereby, without any duress, bless every/all club members...

4a. I doff terribly for Archiival, $X Y, X Y Z$ and $\boldsymbol{A B}$ Chiefesis of ilyas.

b. I absolutely salute former presidents and incumbent presidents of various branches.

5a. Mina awela awala du mina ...I remain my very self... XYZ Songito to power $16 \ldots$ vibrating with a very high frequency via...

b. Me (I)...I remain my very self... a former chorus leader for the past 16 years...speaking with confidence from ...

6a. Let your akarability so shine that komradus will oyoyo the good work of God.

b. Let your destiny shine forth so that members will appreciate the good work of God.

A look at examples (1-6) shows some of the words in use. From their English equivalents, the possibility of non members grabbing the meanings of the words and expressions is very slim, if not impossible. It is also observed from the examples (1-6) above that the word comrado/kowrado (noun) can assume various morphological shapes like comradic (adjective) and komradus (still a noun). Based on the strange meanings attached to the words and expressions by Kegite members, they converge among themselves and diverge from non members. Hence, they are used to establish group identity which in turn differentiates the Kegite club from any other social group. Therefore, through linguistic forms they employ the use of these expressions to converge towards members and diverge from the general public.

TABLE 2:

BRANCH NAMES

\begin{tabular}{|c|c|c|}
\hline \multicolumn{3}{|r|}{ BRANCH NAMES } \\
\hline & Kegite Branch & Location \\
\hline 1 & Ilya du Queen & East London University, London. \\
\hline 2 & Ilya du Afonja & Kwara State College of Education, Ilorin, Kwara State \\
\hline 3 & Ilya du Coconut & Nwafor Orizu College of Edu., Nsugbe, Anambra State \\
\hline 4 & Ilya du Erosion/Ashina & Federal Polytechnic, Oko, Anambra State \\
\hline 5 & Ilya du Oil & Federal College of Education (Technical), Omoku, Rivers State \\
\hline 6 & Ilya du Rock & University of Jos, Plateau Sate \\
\hline 7 & Ilya du Pyramid & Federal College of Education (Technical), Bauchi, Kano State \\
\hline 8 & Ilya du Olumo & Moshood Abiola Polytechnic, Abeokuta, Ogun State \\
\hline 9 & Ilya du Arewa & Kaduna Polytechnic, Kaduna, Kaduna Sate \\
\hline 10 & Ilya du Lagoon & University of Lagos, Lagos State \\
\hline 11 & Ilya du Solar & Federal Polytechnic, Bida, Niger State \\
\hline 12 & Ilya du Calculator & Institute of Accountancy and Basic Studies, Uyo, Akwa Ibom State \\
\hline 13 & Ilya du Chalk & College of Education, Ileha, Osun State \\
\hline 14 & Ilya du Kokoroko & Michael Okpara University of Agriculture, Umudike, Abia State \\
\hline 15 & Ilya du Komputa & Federal University of Technology, Minna, Niger State \\
\hline 16 & Ilya du Engine & Enugu State University of Science and Technology, Enugu State \\
\hline 17 & Ilya du Ancestor & Ancestral Science University, Florida, USA \\
\hline 18 & Ilya du Green Revolution & Samara College of Agriculture, Zaria, Kaduna State \\
\hline 19 & Ilya du Metal & Metallurgical Training Institute of Onitsha, Anambra State \\
\hline 20 & Ilya du Timber & Federal College of Forestry, Ibadan, Oyo Sate \\
\hline 21 & Ilya du Shark & Nigerian Institute for Oceanography and Marine Research Victoria Island, Lagos State \\
\hline 22 & Ilya du Pen & Nigerian Institute of Journalism, Ogba Ikeja, Lagos State \\
\hline 23 & Ilya du Tractor & Federal College of Agriculture, Akure, Ondo State \\
\hline
\end{tabular}


In Table 2, another fascinating feature of the Kegite language can also be seen in the way names are chosen for individual branches of the club. Firstly, it will be observed that Ilya, a seemingly French expression for 'there is' ('il y a') is used to mean 'Kegite branch'. Table 2, examples (1-23) show that the branch names are selected based on feature(s) that characterise(s) the geographical area, where the tertiary institutions are located (observe examples 1-11 in Table 2) and also by using a particular item to represent the academic discipline being studied in these institutions (observe examples 12-23 in Table 2). Based on the first criterion, the capital of England, ruled by the Queen is London. It is based on this that Ilya du Queen is selected (example 1) and in (example 2) Ilya du Afonja is given in memory of the legendary Afonja of Kwara land. Nsugbe is a community known for coconut (this informs the general saying in Igbo about aku oyibo Nsugbe - 'Nsugbe coconut') and this forms the basis of the name Ilya du Coconut (example 3). This applies to examples: (4), where Erosion is used to refer to the land of Oko that is being ravaged by erosion; (5), where Omoku, an oil rich land is named after Oil; (6), where Jos, a land that has many mountains and rocks is named Rock; (7 and 8), where Kano is named Pyramid, after the famous groundnut pyramid of Kano and Abeokuta Olumo after the Olumo Rock located in Abeokuta; (9), where Kaduna being a heartland of the Hausa nation is named Arewa; (10), where Lagos, known for many water bodies is named Lagoon and (11), where Bida is named Solar after the popular solar energy supply provided by former Nigerian President, Gen. Babangida throughout his villa. However, for one to appreciate the beauty of these names, one must have background information of these locations to be able to interpret the names accordingly. On the other hand, concepts that characterise academic disciplines being pursued in tertiary institutions are also used to coin names for club branches. Hence calculator is used for an institute of accountancy, chalk for a college of education and kokoroko (a typical onomatopoeic name for a cock) for a university of agriculture in examples (12-14) respectively. This is also the case in examples (15-23). Uniquely, these names are used to establish group identity, such that instead of using 'branch' or 'chapter', ilya du is used. And instead of using the formal names of the campuses, unique names are coined for each campus, thereby rebuffing adherence to names used by the general public. In addition, depending on the context of use, ilya can also mean relax/feel at home (see example 9 below). Observe examples (7-12) below.

7a. It is written in da book of bookosis, chapter nkwu verse ngwo dat when two or more entities are in Gaddaffi, an ilya is formed.

b. It is written in the Kegite book of books that when two or three people(Kegite members) come together, a Kegite branch is formed.

8a. May the gods bless all am karid...via ilya du Kokoroko bembestically.

b. May the gods bless all the (Kegite )members...from Michael Okpara University of Agriculture, Umudike abundantly.

9a. ...I too hoties by the wizard of capitosis is to make all homies feel at ilya.

b. ...I am also, through the wisdom represented by the cap (I am wearing) entrusted with the responsibility of making everybody to feel at home.

10a. ... I remain my very self...XYZ Songito to power 16 via ilya du Pyramid...

b. ...I remain my very self... a former chorus leader for the past 16 years in Federal College of Education (Technical), Bauchi...

11a. By da eldersis council ilya du ashina I kuet, happy monica two all adim karid. May you walk bembestically and never stumble.

b. As a member of the council of elders, Federal Polytecnic, Oko, I say(speak), happy Monday to all members of the Kegite club. May you walk majestically and never stumble (may no evil befall you).

12a. ...minawela awolu doss on ma 2 leggesis to prayamus ana juru pepe to all adikwa $m$ karid in dis abuna ilya.

b. I am on my two knees praying and interceding for all Kegite members of our branch.

The different contexts of use of ilya make for the lucidity of the word and present its various manifestations and senses in different contexts. Based on CAT, group solidarity among members is once again achieved through convergence and non members are kept at an arm's length through divergence based on the arbitrary senses in the linguistic forms of the expressions which are not comprehensible to the general public. It is also important to note here that Kegite expressions appear in two physical forms - familiar and strange forms. Familiar expressions are those expressions that contain content words, whose possible interpretations mean something to non-members. Let us consider example (7), when a non-member hears that "...when two or more entities are in Gaddafi, an ilya is formed". $\mathrm{S} /$ he is likely going to interprete it to mean "... when two or more people who behave like Muammar Gaddafi of Libya come together, a revolutionary group is formed". But that is not the case. So, such expressions are familiar but their meanings are strange. In other words, what a familiar expression in the Kegite language appears to mean is always entirely different from what it actually means. On the other hand, strange expressions refer to those expressions that are completely strange to non-members because they do not have familiar lexical items common with expressions of the general public. Let us consider example (12). Expressions like (12) above appear completely strange to non-member and leave them with no clue of what the meanings could be. 
TABLE 3:

DISTORTED FORMS

\begin{tabular}{|l|l|l|}
\hline S/N & Kegite expression & Gloss/Meaning \\
\hline 1 & Dia (3+1) & Therefore \\
\hline 2 & Rot8 & Rotate \\
\hline 3 & Bookosis/booko6 & Plural form for book (books) \\
\hline 4 & Chiefesisi/chiefe6 & Plural form for chief (chiefs) \\
\hline 5 & Songito & Singer \\
\hline 6 & Drummito & Drummer \\
\hline 7 & Opendensial & Open \\
\hline 8 & Munwaness & Myself \\
\hline 9 & Guaness & You (in particular) \\
\hline 10 & Yanwaness & Himself/herself \\
\hline 11 & Okpekesis/opeke6 & Plural form for okpeke 'female' \\
\hline 12 & Okpakasis & Plural form for okpaka 'male' \\
\hline
\end{tabular}

Table 3 above shows how linguistic forms are manipulated in the Kegite language. We see how forms could be truncated for shorter renditions, especially in writing $-\operatorname{dia}(1+3)$ for 'therefore' and $\operatorname{rot} 8$ for 'rotate' (see examples $1 \& 2$ in Table 3). Examples (3-7) may be called 'English' in some sense but we cannot out rightly say that these varieties represent the English language. Instead of adding an -s to 'chief' and 'book' to derive the plural forms, -osis and -esis are added to form plurals respectively in examples $(3 \& 4)$. Same goes for examples $(11 \& 12)$. Again, English grammatical rule of using -er to derive agentive nouns from verbs is also ignored in examples $(5 \& 6)$ giving rise to a 'corrupt' form of 'singer' (sungito) and 'drummer' (drummito) respectively. Kegite agentive nouns from the data presented in Table 3 are formed using its own morpheme -ito. In addition, instead of simply saying 'open', opendential is used in example (7). Likewise, the words in examples (8-10) possess partly Igbo (munwa 'me', gunwa 'you'and yanwa 'him/her') words and English suffixes, -ness and (11 \& 12) are Edo words pluralised using the Kegite plural morpheme, -sis. However, despite the high arbitrary nature of the Kegite language, it is remarkable how members understand one another. Hence, they communicate perfectly well among themselves, at the same time, they keep the general public in the dark. To further show the manifestation of convergence among Kegite members and divergence from non members, observe their use of these words in the following sentences (12-16) below.

13a. Okpekesis/okpeke6 are meant for chiefesis/chiefe6 consumption.

b. Women are meant for presidents' enjoyment.

14a. Munwaness ... sound a note of warning.

b. Me (I) ... sound a note of warning.

15a. Okpekesis letter ' $\mathrm{O}$ ' remaindath theory a wogged opendential keske of surunyu.........

b. A woman's virgina is always open for sex...

16a. Even on dat matrimonica day D in D holy bookosis of Felo Jesus...He tinaturned water to emuogor.

b. Even on the wedding day as recorded in Jesus' holy book (Bible)....He turned water into wine.

17a. ...you have fired to my timpamic membrane, may it be so for giwaness/guaness.

b. ... you have really thrilled me, may it be so for $\boldsymbol{y o u}$.

The peculiar way the words are used in (13-17) is also an indication of Kegite linguistic forms displaying some distinctive characteristics that set it apart from the language of the general public. As an out-group, when one hears them speak, making use of these expressions, one eventually gets confused even as one tries to isolate common/familiar words that appear in the expressions and attempts to use the meanings of those common words to arrive at the meanings of the expressions. Let us take the expression in example (15) as an instance. An attempt to isolate the meanings of common words like $O$ and theory, and use them to arrive at the meaning of the entire expression, gets an out-group listener confused because these common meanings do not contribute to the actual meaning of the expression. 
TABLE 4:

TERMS RELATED TO THE ACTIVITIES/WORLD VIEW OF THE CLUB

\begin{tabular}{|c|c|c|}
\hline $\mathrm{S} / \mathrm{N}$ & Kegite expressions & Gloss/Meaning \\
\hline 1 & Chief & President of the club \\
\hline 2 & Comrades/Kongosis & Student members \\
\hline 3 & Intercontinental lalala & Anthem \\
\hline 4 & Regaliate 4/4 & Being fully dressed \\
\hline 5 & Karid & Member/(you)belong \\
\hline 6 & Animal & Non-Kegite member \\
\hline 7 & Shrine & $\begin{array}{l}\text { A warehouse where all club materials are kept and a relaxation place for } \\
\text { comrades and their visitors }\end{array}$ \\
\hline 8 & Migration & Movement of the Kegites group outside their locality \\
\hline 9 & Coronation & Induction of a new chief \\
\hline 10 & Liberation & Inauguration of new members \\
\hline 11 & Agogorization & Announcement \\
\hline 12 & G-Lord/Grand Lords & Executive members \\
\hline 13 & Baby ilya & $\begin{array}{l}\text { An uncommissioned branch of Kegite club which has no coroneted chief } \\
\text { yet and a keg of office }\end{array}$ \\
\hline 14 & Omoba & A selected but yet to be coroneted chief \\
\hline 15 & Keg of Office & A Keg/calabash that symbolises authority of a commissioned Branch \\
\hline 16 & Swahili & The approved language of Kegite club \\
\hline 17 & Zoo & A place where new members are groomed and lectured about the club. \\
\hline 18 & Ozoemena & (Igbo name meaning 'It should not re-occur') Death \\
\hline 19 & Holy water/ $\mathrm{H}_{2} \mathrm{O}$ & Palm wine \\
\hline 20 & Poison & Any other drink outside palm wine \\
\hline 21 & Junior foreign poison & Soft drink \\
\hline 22 & Senior foreign poison/higher killer & Hot drink \\
\hline
\end{tabular}

Items in Table 4 above give insight into the worldview of the Kegite. For instance, they see the president of their club as chief and his induction as coronation, while a yet to be inducted chief is an Omoba (a Yoruba name for 'prince'), just as in a typical African setting, reflecting cultural influence; the club is regarded as a unit, this informs the use of comrade (and its various variants) for members of the club and anybody who is karid belongs to Kegite (see examples 1 , $9,14,2 \& 5)$. An anthem is usually a unifying factor, hence; anthem is referred to as something intercontinental, such that irrespective of where the branch is located, the values of the club must be upheld (example 3 ). Their worldview is also portrayed in how they refer to places, activities, their official language, non members and events like death as we can see in examples (5-18) of Table 4. Again, a look at examples (19-22) shows the rating between palm wine and any other drink in the society. We can rightly say that just like every other kind of slang, the language of the Kegite is quite casual and metaphorical. This could be seen through some of their expressions like poison which means 'drinks other than palm wine', a crude metaphor for non native drinks. These expressions show solidarity and intimacy of the Kegite members and by extension, the expressions also perform the function of inclusion of members and exclusion of nonmembers during interaction. Observe some of the expressions in higher constructions as in (17-21).

18a. Komrados to regaliate 4/4 to komradic activites.

b. (Kegite club) members are to dress fully to club activities.

19a. Songito, de intercontinental lalala.

b. Chorus leader, (lead us in) the Kegite anthem.

20a. Animals are highly present in dis area we.

b. Non Kegite members are many in our area (environment).

21a. ...da attempt attepted by gunwaness to vibrate outside $\mathbf{S w a h i l i . . .}$

b. ...the offense committed by you to speak without using the official language of the club...

22a. Da shrine all over the galagala attempt with opendensial mind the majestic holy water...never destroy poison plus da senior or junior, local or foreign poison. Da poison, komradus shall not attempt there.

b. The club's secretariat/warehouse all over the world generously accommodates palm wine...do not drink any other drink other than palm wine, even the soft or hot drink, locally or foreign made. Members shall not drink or keep any other drink except palm wine there (in the secretariat).

23a. Let the G-Lords (Grand Lords) shine their $99.99 \%$ for the upliftment of komradum.

b. Let the executive members do their best for the welfare of (Kegite) members.

Examples (18-23) present an interesting picture of the Kegite linguistic forms performing an exclusive function for non members. For instance, the structure of example (20) appears like the English language structure but the rearrangement of linguistic items in the construction does not conform to the standard syntactic arrangement of lexical items in English. This syntactic rearrangement adds a Kegite flavour to the expression. However, even when a nonmember tries to figure out the sense in the expression (despite the rearrangement of linguistic items) the meaning of "animal" in the expression makes it difficult or impossible to comprehend. Again, listening to Kegite members interact keeps a non-member listener busy shuttling between two or more languages - English, French, NPE and indigenous Nigerian languages, to sieve out the possible meanings in the expressions, which eventually fails to offer the correct meaning(s) intended or expressed. For instance, the last word in example (20) - we sounds like the French 'oui' - 'yes'. 
Hence a non-member may take the expression to mean "There are many (domestic) animals (running around) in this area, yes." The use of 'yes' suggests to the hearer that the expression, maybe, agrees with an already stated fact. Therefore, as the listener tries to make sense of these expressions, s/he gets even more confused and consequently, s/he is completely left behind in the conversation. In addition, the repetition of linguistic items to show a unique sense as in (21) is another feature of the Kegite language.

TABLE 5:

COMPLEX EXPRESSIONS FOR SIMPLE EXPRESSIONS

\begin{tabular}{|l|l|l|}
\hline S/N & Kegite expression & Gloss/Meaning \\
\hline 1 & Washington DC OR Interact with the frequency of mammy water & Bath \\
\hline 2 & Benue state/answer Bendel & Bend down \\
\hline 3 & Da dee minus one (That day minus one) & Yesterday \\
\hline 4 & Opundensial & Open \\
\hline 5 & Opundensial in a revise gear/..in a rivers state & Close \\
\hline 6 & Enyemaka ngwaa & Help \\
\hline 7 & Agbataekulu nwa/permanent selotaping & Marriage \\
\hline 8 & Trade by barter & Market \\
\hline 9 & Operation feed the nation & Farming \\
\hline 10 & Nawali/Nasarawa & Now \\
\hline 11 & Eligwe chamber/NEPA & Sunshine \\
\hline 12 & Obey the law of gravity & Sit down/fall \\
\hline 13 & Disobey the law of gravity & Stand up/get up \\
\hline 14 & National assignment precise & Office \\
\hline 15 & Agrippa, Iweka road & Angry \\
\hline 16 & Junior foreign poison & Soft drink \\
\hline 17 & Senior foreign poison/higher killer & Hot drink \\
\hline 18 & Eligwe chamber titration & Rainfall \\
\hline 19 & Behind time & Late \\
\hline 20 & Minawela awolu & Me \\
\hline 21 & Mina wela atete awela awolus & Me \\
\hline
\end{tabular}

24a. Entities to bendalise, entities to answer bendel republic, chiefesis to connect...

b. Members are requested/expected to bend down/bow their heads, chiefs(presidents) are expected to (spiritually) connect (with the gods)...

25a. Mina awela awala du mina ... I remain my very self... XYZ Songito to power $16 \ldots$

b. Me (I)... I remain my very self... a former chorus leader for the past 16 years...

26a. Since da dee minus one till da dee go moronto...

b. Since yesterday till today and even tomorrow...

27a. ... I remaindath dat same coconut that tried tawinjirization with mammy water via River Niger...........

b. ...I remain that same person who has ever taken his bath in the depth of the river Niger.../ (...I am that same brave man who has done the impossible...)

28a. My karability is made wogged via da enyemaka ngwaa of my XYZ Chief...

b. My destiny was sharpened/I was inducted by/through the help of my former president...

29a. Am made in Lagoon nawali. Okpeke interact.

b. I am in Lagos now/currently. Any babe/girl within the vicinity can contact me.

Table 5 shows long expressions that stand for simple concepts in the general world. As observed by Achebe (1958), a typical African man does not speak in plain language not garnished with adages. This art of knowing how to manipulate words to pass across information in figurative language is highly cherished in African societies. It is a mark of wisdom and oratory competence. This could be seen in the expressions presented in Table 5, where a single word like 'me' could be said using an expression as long as Minawela atete awela awolus as in example (21). Though the long expressions sampled in Table 5 portray African orientation, they are not expressions used by the general public. Therefore, only Kegite members make use of and understand them and as such, non members are at a loss as to what they mean.

Furthermore, some of the senses are metaphorical in nature. Observe items 7, 11, 12, and 13 in Table 5. In item 7, permanent selotaping stands for marriage, where the couple will forever remain one (glued together) through their marital vows before the priest(s) and the congregation. In the same vein, item 11 eluigwe chambers (sky) or NEPA (National Electricity Power Authority), the ministry that was once in charge of Electricity generation in Nigeria, means sunshine. Also, obeying and disobeying the law of gravity as in items 12 and 13 are unique ways of expressing the senses of sitting and standing. Expressions in Table 5 as well as the structures where they occur as in examples (24-29) are used by members to identify with the group as well as to ensure that non members are excluded from their conversation. In other words, they fulfil CAT's convergence/divergence principle. Hence, instead of going straight to the point and saying what they want to say out rightly, Kegite members love playing around with words. Let us consider a fuller version of (25a) as we have it in (25c) below:

25c. Mina awela awala du mina, where Amina has decided to go in skirt and blouse, that is to say, I remain my very self... 
A look at (25c) may suggest to a non-member listener that the speaker is probably talking about an 'Amina' (a person) who has decided to put on skirt and blouse without knowing that everything said from 'Mina...' to '...blouse' in the construction is a way of saying 'I'. The long expression does nothing more than adds beauty to the expression (in this case, 'I').

TABLE 6:

KEGITE SAYINGS

\begin{tabular}{|l|l|l|}
\hline S/No & Kegite Expression & Meaning/Equivalence in the General Society \\
\hline 1 & A house that is divided against itself shall stand - unity in diversity & A house divided against itself shall fall. \\
\hline 2 & Few are called but many are chosen & Many are called but few are chosen. \\
\hline 3 & By their fingers you shall know them & By their fruits you shall know them \\
\hline 4 & Okpaka wey dey titrate must stand at ease & A male who is urinating must stand straight \\
\hline 5 & The evils that okpekesis do live with them for nine months & $\begin{array}{l}\text { The evils that men do live after them -(this is related to } \\
\text { females and unwanted pregnancy) }\end{array}$ \\
\hline 6 & One day is for the okpakasis, nine months is for the okpekesis & Every day is for the thief but one day is for the owner. \\
\hline 7 & A comrade is never late, he may only come behind the time & Showing Kegite members as superior to non-members \\
\hline 8 & A comrade does not eat, he feeds & Showing Kegite members as superior to non-members \\
\hline 9 & A comrade does not drink, he evaporates & Showing Kegite members as superior to non-members \\
\hline 10 & A comrade never forgets although he may fail to remember & Showing Kegite members as superior to non-members \\
\hline 11 & A comrade never falls, he may only obey the law of gravity & Showing Kegite members as superior to non-members \\
\hline 12 & Turu pepe turu pepe, the head of agbalagba is not meant for a child's play & Serious things should not be played with. \\
\hline
\end{tabular}

Table 6 above shows 'liberal' language used by the Kegite club to rebuff conformity, compliance and allegiance to the mainstream society and the existing order of things. It portrays a refusal to accept what is generally accepted to be the norm. For example, the status quo is 'Many are called but few are chosen' but a Few are called but many are chosen shows an attitude of rebellion against the norm. Examples ( $5 \& 6$ ) refer to women and unwanted pregnancy, which are not generally implied as the English equivalents. This is an encouragement to break off from what is considered 'standard', a stylistic variety occupying an extreme on the spectrum of linguistic convention and formality. This kind of language emphasises group intimacy and solidarity, thereby performing the social function of both inclusion and exclusion (inclusion of members and exclusion of non members) as proposed in CAT.

\section{SUMMARY OF THE FINDINGS}

The language of the Kegite club is somewhat complex and exhibits variety in form and in function. Some of the words used in the Kegite language like every other human language, found their ways into the lexicon through the creative nature of individual members. With frequent usage, these words are integrated into the language and they spread through the various ilyas (branches); for instance, the use of $A B$ for 'current', 'present' or 'incumbent' and $X Y$ for 'immediate past'. The way these coinages are used within the club is one of the major factors that strengthen the Kegite club.

The language of the Kegite club comprises of linguistic items that could be seen in the general linguistic environment. Since the Kegite club exists within a larger society, it is in contact with other language(s) of the larger society through the speakers. Therefore, words are lifted from language(s) used in the society. For instance, the word 'keg' is an English word for a container (example: keg/gourd of palm wine). The suffix '-ite' is added to 'keg' to derive Kegite, which now refers to the members of the Palm Wine Drinkers Club. Furthermore, Ilya du, which sounds French (like the French word 'il y a' meaning 'there is' and 'de' or 'du' meaning 'of') are used to mean 'place of' in the Kegite language. It finds its way into the vocabulary of the Kegites' language to mean 'setting', that is, a geographical location or campus or branch of the club. We can also see some Kegite expressions that we can trace their roots to some indigenous Nigerian languages. For instance, the words for man and woman, 'okpaka' and 'okpeke' respectively, obviously are traced to 'okpaka' of Edo of Delta region of the south southern Nigeria meaning 'men' and 'okpeke' which stands for 'women'. These words are sometimes clipped and blended in a unique way to make them appear different from what they are in the source languages. We can, therefore, say that the Kegite language is furnished from English, French and indigenous Nigerian languages.

Despite the sources of the linguistic items used in the Kegite language, the items have their specific forms (which are sometimes truncated or distorted from their original forms) and meanings (which are metaphorical) within the context of the club. Generally, the formation, structure, as well as language use of the Kegite exhibit certain pidgin or pidginlike attributes that is however, quite different from the Nigerian Pidgin. Nevertheless, the features of the Kegite language from our observation based on our data analysis make it a specific type of slang and not pidgin. All these in turn, make the language a tool with which Kegite members align with the group and group identity as well as move away from non-members of the club as postulated in CAT.

Finally, we can say that Kegite expressions appear in two forms - simple familiar or complex strange expressions. The familiar expressions at first appear familiar and understandable because they contain obvious familiar words used by the general public but they are actually not what the non-members take them to mean. The complex strange expressions on the other hand do not contain familiar words that could suggest their meanings to non-members. Therefore, they appear strange from the onset and leave no clue(s) about their meanings. Both kinds of expression leave 
non-members in the dark and socially far away from Kegite members. The Kegite language, therefore, is a tool with which the club members converge with each other and at the same time diverge with non-members. As such, members of the club do not necessarily need non-members to leave their presence when they do not want them to be part of what they are discussing. They only have to communicate in their language and a non-member is automatically excluded.

\section{CONCLUSION}

Just like any other functional language variety, the Kegite language contains quite a number of expressions, which are intelligible to only the members of the club. These expressions are strange to non-member of the club, but they are as common as every other day-to-day expression in the common/general language of the speech community to the Kegite members. English can be said to be the root of the Kegite language since it is the dominant language found in the expressions. This is because English is the lingua franca in Nigeria and the language commonly spoken in the country's tertiary institutions. However, one cannot say that the Kegite language is a typical variety of Nigerian English. So, it can be rightly said that the Kegites have developed a specific type of slang from the various languages at its disposal. The slang so developed is not simply an anomaly or an aberration created by some crude and deviant characters; it is rather an essential part of a dynamic sociolinguistic structure, reflecting the social and aesthetic needs and desires of man. Moreover, the Kegite club applies these expressions as tools with which they identify with members of the club. They function as unifying factors that unify the group, thereby converging towards club members. The slang also serves as a tool that draws them apart from the general public/non-members. In this respect, they diverge away from those who are not members of the club.

\section{REFERENCES}

[1] Achebe, C. (1958). Things fall apart. London: Heinemann.

[2] Afolabi, O. A. (2011). A sociolinguistic study of the Kegites (palm wine drinkers club) language. Available on www.bukisa.com. Assessed on 20/07/2015.

[3] Ari, H. (2011). An analysis of slang terms in the American Gangster. A movie directed by Ridley Scott. M.A. Thesis, University of Syarif, Hidayatullah.

[4] Bernstein, B. (1958). Some sociological determinants of perception: An inquiry in sub-cultural differences. British Journal of Sociol, 9, 159-174.

[5] Bernstein, B. (1960). Language and social class. British Journal of Sociology, 11, 271-276.

[6] Bernstein, B. (1971). On the classification and framing of educational knowledge. In M. Young (Ed.), Knowledge and control. London: Collier-Macmillan.

[7] Burdová, V. (2009). Student slang. M.A. Thesis, Masaryk University, Brno.

[8] Crystal, D. (1994). Cambridge encyclopaedia of language. Cambridge: Cambridge University Press.

[9] Coupland, N. \& Giles, H. (1988). The communicative contexts of accommodation. Language and Cognition, 8(3/4), 175-182.

[10] Dittmar, N. (1976). Sociolinguistics: A critical survey of theory and application. London: Edward Arnold.

[11] Gilbert, U. O. (2013). Book of bookosis (Kegites encyclopaedia). A handbook of the Kegite Club.

[12] Giles, H. (1971). Patterns of evaluation to R.P., South Welsh and Somerset accented speech. British Journal of Social and Clinical Psychology, 10(3), 280-281.

[13] Giles, H. \& Baker, S. C. (2008). Communication accommodation theory. In W. Donsbach (Ed.), The international encyclopaedia of communication. Blackwell Reference Online.

[14] Giles, H. \& Ogay, T. (2007). Communication accommodation theory. In B. B. Whaley \& W. Samter (Eds.), Explaining communication (pp. 325-344). New Jersey: Lawrence Inc.

[15] Giles, H., Coupland, J. \& Coupland, N. (1991). Contexts of accommodation: Developments in applied sociolinguistics. Cambridge: Cambridge University Press.

[16] Giles, H. \& Coupland, N. (1991). Language: Context and consequences. Milton Keynes: Open University Press.

[17] Halliday, M. A. K. (1964). The users and uses of language. In M. A. K. Halliday, A. Mclntosh \& Strevens (Eds.), The linguistic science and language teaching (pp. 75-110). London: The Hague.

[18] Hudson, R. A. (1996). Sociolinguistics (2nd Ed.). Cambridge: Cambridge University Press.

[19] Jorgen, A. (2010). Slang lexicography and the problem of defining slang. Paper presented at the fifth international conference on historical lexicography and lexicology, Oxford.

[20] Labov, W. (1966). The social stratification in New York City. Cambridge: Cambridge University Press.

[21] Mattiello, E. (2008). An instruction to English slang: A description of its morphology, semiotics and sociology. Milano: Polimetrica.

[22] Mish, F. C. (Ed.). (2003). Merriam-Webster's collegiate dictionary (11th edition). Springfield, Massachusetts: MerriamWebster, Incorporated.

[23] Ndimele, O. M. (1999). Semantics and frontiers of communication. Port Harcourt: University of Port Harcourt Press Ltd.

[24] Oladokun. A. (1982). The palm wine drinkers' club. The Nigerian Field, 47(1-3), 3-5.

[25] Partridge, E. (1933). Slang today and yesterday. London: Routledge and Kegan Paul Limited.

[26] Ratna, P. S. (2010). An analysis of slang language types in Rush Hour 2 movie. M.A. Thesis, Islamic State University, Jakarta.

[27] Spolsky, B. (1998). Sociolinguistics. Oxford: Oxford University Press.

[28] Street, R. L. \& Giles, H. (1982). Speech accommodation theory: A social cognitive approach to language and speech behaviour. In M. Roloff \& C. R. Berger (Eds.), Social cognition and communication (pp.193-226). Sage: Beverly Hills.

[29] Turner, L. H. \& West, R. (2010). Introducing communication theory: Analysis and application (4th ed.). New York: McGraw Hill. 
[30] Trudgill, P. (1992). Ausbau sociolinguistics and the perception of language status in contemporary Europe. International Journal of Applied Linguistics, 2(2), 167-177.

[31] Valdman, A. (2000). La langue des faubourgs et des banlieues: De l'argot au Français populaire. The French Review, 73(6), $1179-1192$.

[32] Wilson, S. R. (2007). Communication accommodation theory. In B. B. Whaley \& W. Samter (Eds.), Explaining communication (pp. 77-112). New Jersey: Lawrence Erlbaum Associates Inc.

[33] Zazulak, S. (2016). Using English slang in your conversations. Available in www.englsih.com/blog. Accessed on 29-09-2016.

[34] Zotevska, E. (2013). Representation of British teenage slang in the TV-series Misfits: A communicative approach to teenage slang. B.A. Project, Goteborgs Universitet.

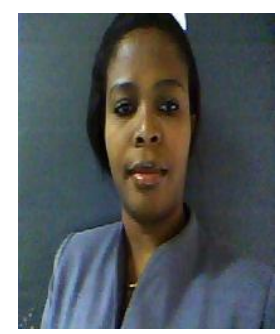

Gloria Tochukwu Okeke was born at Ajalli in Anambra State, Nigeria. She attended the University of Nigeria, Nsukka and graduated in 2008 with a B.A. (Linguistics) Second Class Honours (Upper Division). In 2013, she registered for her master's degree and graduated with an M.A in Applied Linguistics. Presently, she is running her Ph.D. in Applied Linguistics in the University of Nigeria, Nsukka. She is also a lecturer in the Department of Linguistics, Igbo and Other Nigerian Languages, University of Nigeria, Nsukka.

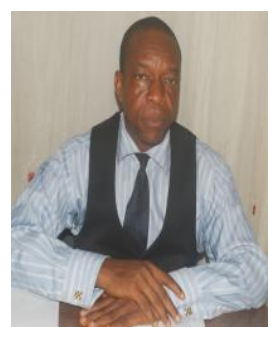

Boniface Monday Mbah is a professor of Linguistics in the University of Nigeria, Nsukka, and also a lawyer. Prof. Mbah is from Orba in Enugu State, Nigeria. He has more than 80 publications in both local and international journal. His areas of interest are: morphology, syntax and semantics. He has served as the editor to many reputable journals in Nigeria, and a member of various professional associations.

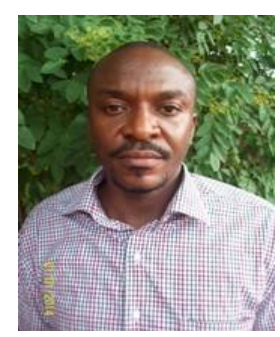

Chukwuma Onyebuchi Okeke was born at Awgu in Enugu State of Nigeria. He is a lecturer in the University of Nigeria, Nsukka. He is a fellow of the African Humanities Programme (AHP) organized by the American Council of Learned Society (ACLS). He is interested in the core areas of Linguistics via phonology, morphology, syntax and semantics. 